\title{
A study of the etiology of transient congenital hypothyroidism in Niigata Prefecture, Japan
}

\author{
Keisuke Nagasaki ${ }^{*}$, Satoshi Narumi ${ }^{2}$, Kiyomi Abe ${ }^{2}$, Tadashi Asami ${ }^{3}$, Hidetoshi Sato ${ }^{1}$, Yohei Ogawa ${ }^{1}$, Toru Kikuchi ${ }^{1}$, \\ Tomonobu Hasegawa ${ }^{2}$, Akihiko Saitoh ${ }^{1}$
}

From 7th APPES Biennial Scientific Meeting

Nusa Dua, Bali. 14-17 November 2012

\section{Background}

Several conditions have been known to causetransient congenital hypothyroidism (TCH), including transplacental passage of TSH receptor blocking antibody (TSBAb), maternal antithyroid drug usage, iodine deficiency, iodine excess, fetal prematurity and inactivatingDUOX2mutations. However, the underlying etiology of $\mathrm{TCH}$ is not determined in some cases. In this study, we conducted the first systematic investigation on the etiology of $\mathrm{TCH}$, using screening population-based cohort in Niigata Prefecture, Japan.

\section{Methods}

Between April 2003 and March 2009, 148,100 newborns were screened for $\mathrm{CH}$ in Niigata prefecture, and 159 patients were considered positive for $\mathrm{CH}$. We diagnosed patients as having $\mathrm{TCH}$ that fulfilled the following two criteria: 1) serum TSH level $>30 \mathrm{mU} / \mathrm{L}$ and serum FT4 level $<1.5 \mathrm{ng} / \mathrm{dLat}$ the initial examination, 2) serum TSH level $<5 \mathrm{mU} / \mathrm{L}$ while investigative discontinuation of thyroxine replacement at 2 years of age. A total of 9 patients $(1 / 16,500)$ diagnosed with TCH were evaluated. To determine the etiology of $\mathrm{TCH}$, we examined the following: 1) maternal medical history, 2)gestational age and birth weight, 3) maternal anti-thyroid antibodies, 4) urinary iodine concentration at initial visit, and 5) DNA sequence of DUOX2.
'Division of Pediatrics, Department of Homeostatic Regulation and Development, Niigata University Graduate School of Medical andDental Sciences, Niigata, Japan

Full list of author information is available at the end of the article

\section{Results}

Among the nine $\mathrm{TCH}$ patients, one had extremely high maternal TSBAb level, one was exposed to propylthiouracil, and two were exposed to excessive iodine.Furthermore, we found that five had biallelicDUOX2 mutations.

\section{Conclusions}

DUOX2 mutations were the majorcause of $\mathrm{TCH}$ in our cohort study.

\section{Authors' details}

'Division of Pediatrics, Department of Homeostatic Regulation and Development, Niigata University Graduate School of Medical andDental Sciences, Niigata, Japan. ${ }^{2}$ Department of Pediatrics, Keio University School of Medicine, Tokyo, Japan. ${ }^{3}$ Department of Nursing, Faculty of Nursing, Social Welfare, and Psychology, Niigata Seiryo University, Niigata, Japan.

Published: 3 October 2013

\section{doi:10.1186/1687-9856-2013-S1-055}

Cite this article as: Nagasaki et al: A study of the etiology of transient congenital hypothyroidism in Niigata Prefecture, Japan. International Journal of Pediatric Endocrinology 2013 2013(Suppl 1):055.

Submit your next manuscript to BioMed Central and take full advantage of:

- Convenient online submission

- Thorough peer review

- No space constraints or color figure charges

- Immediate publication on acceptance

- Inclusion in PubMed, CAS, Scopus and Google Scholar

- Research which is freely available for redistribution

Submit your manuscript at www.biomedcentral.com/submit 